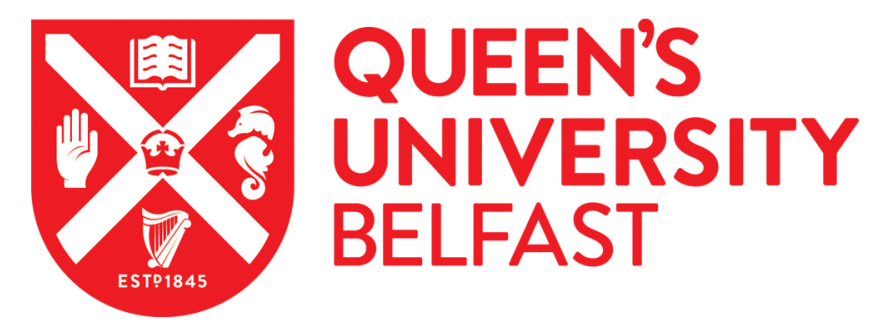

\title{
Simulation model suggests that fire promotes lodgepole pine (Pinus contorta) invasion in Patagonia
}

Davis, K. T., Maxwell, B. D., Caplat, P., Pauchard, A., \& Nuñez, M. A. (2019). Simulation model suggests that fire promotes lodgepole pine (Pinus contorta) invasion in Patagonia. Biological Invasions. https://doi.org/10.1007/s10530-019-01975-1

Published in:

Biological Invasions

Document Version:

Peer reviewed version

Queen's University Belfast - Research Portal:

Link to publication record in Queen's University Belfast Research Portal

Publisher rights

(C) 2019 Springer Nature Switzerland AG. This work is made available online in accordance with the publisher's policies. Please refer to any applicable terms of use of the publisher.

\section{General rights}

Copyright for the publications made accessible via the Queen's University Belfast Research Portal is retained by the author(s) and / or other copyright owners and it is a condition of accessing these publications that users recognise and abide by the legal requirements associated with these rights.

Take down policy

The Research Portal is Queen's institutional repository that provides access to Queen's research output. Every effort has been made to ensure that content in the Research Portal does not infringe any person's rights, or applicable UK laws. If you discover content in the Research Portal that you believe breaches copyright or violates any law, please contact openaccess@qub.ac.uk. 
1 Title: Simulation model suggests that fire promotes lodgepole pine (Pinus contorta) invasion in 2 Patagonia

3

4 Kimberley T. Davis ${ }^{1 *}$, Bruce D. Maxwell ${ }^{2}$, Paul Caplat ${ }^{3}$, Aníbal Pauchard ${ }^{4,5}$, Martin A. Nuñez ${ }^{6}$ 5

$6{ }^{1}$ Department of Ecosystem and Conservation Sciences, University of Montana, 32 Campus Dr., 7 Missoula, MT, 59812, USA

$8 \quad{ }^{2}$ Land Resources and Environmental Sciences Department, Montana State University, Bozeman, 9 MT 59717, USA

$10{ }^{3}$ Institute for Global Food Security, School of Biological Sciences, Queen's University Belfast, 11 Belfast, Northern Ireland, United Kingdom

$12{ }^{4}$ Laboratorio de Invasiones Biológicas (LIB). Facultad de Ciencias Forestales, Universidad de 13 Concepción, Casilla 160-C, Concepción, Chile

$14{ }^{5}$ Institute of Ecology and Biodiversity (IEB), Las Palmeras 3425, Casilla 653, Santiago, Chile

${ }^{6}$ Grupo de Ecologia de Invasiones, INIBIOMA, CONICET, Universidad Nacional del Comahue,

16 Quintral 1250, San Carlos de Bariloche, CP 8400, Argentina

$17{ }^{*}$ Corresponding author

18 Email: Kimberley.Davis@umontana.edu

19 Phone: (401) 787-7456

20 ORCID ID: 0000-0001-9727-374X 


\section{Abstract}

To best understand plant invasions and predict unexpected outcomes it is necessary to integrate information on disturbance, the local environment, and demography. Disturbance by fire has been shown to promote invasions worldwide, but precise interactions between fire, native and invading species remain unclear. Indeed, trade-offs exist between fire-induced mortality of seed sources and increased establishment, driving invasion outcomes. A positive feedback between lodgepole pine (Pinus contorta) invasions and fire has been identified but only above a certain pine density. Above this threshold, fire resulted in increased pine dominance at the plot level, however below this threshold establishment rates did not change. We used a spatially explicit invasion simulation model modified to include fire to explore the implications of these complex interactions between pine invasions and fire. We asked if fire promoted $P$. contorta invasion across a Patagonian steppe site and if this depended on the age of the invasion when it burned. Our simulations indicated that, although fire was not necessary to initiate invasion, fire in communities where pine invasions were at least 10 years old resulted in increased spatial extent and maximum invasion density compared to unburned simulations. Fire through younger invasions did not alter the progression of the invasion compared to unburned simulations. Pine invasions should be managed before they reach an advanced stage where positive feedbacks between fire and pine invasion could lead to dramatic increases in invasion rate.

Keywords: biological invasion, fire, Pinus, positive feedback, simulation model, tree invasion 


\section{Introduction}

(1)

Plant invasions that have the capacity to alter fire regimes and create positive feedbacks with fire have the potential to cause significant impacts on native ecosystems (Mack and D'Antonio 1998; Brooks et al. 2004; Gaertner et al. 2014). Although many studies have examined how invasive plants alter fire regimes (e.g. van Wilgen and Richardson 1985; Rossiter et al. 2003; Pauchard et al. 2008; Balch et al. 2013), few have integrated information on invasion-fire feedbacks to study the effects of these complex interactions on invasion extent. Integrating feedbacks and population dynamics is necessary to determine how fire across a landscape will alter invasion spread and consequently invasion impacts on native communities. Disturbance is widely believed to increase invasion success for many plant species by creating an invasion window with increased resource availability (Johnstone 1986; Sher and Hyatt 1999; Davis et al. 2000). For pine species (genus Pinus) introduced to the Southern Hemisphere, invasion is often correlated with human-caused or natural disturbances (Richardson and Bond 1991; Richardson et al. 1994). In particular, fire has been found to promote the invasion of Pinus radiata, P. pinaster, and P. halepensis into South African fynbos (Richardson and Cowling 1992) and P. halepensis into the Argentine Pampas grasslands (Zalba et al. 2008). Additionally, areas dominated by tall shrubs that are generally resistant to invasion by Pinus contorta (Taylor et al. 2016a) were significantly more vulnerable after fire (Taylor et al. 2017). Other studies suggest that when disturbance is more likely in invaded than uninvaded areas it may actually decrease the likelihood of further invasion, due to tradeoffs between increased invader habitat quality in disturbed areas and disturbance-induced invader mortality (Buckley et al. 2007). Therefore, it is necessary to consider both the negative and positive effects of disturbance on invasion when predicting landscape-level changes in invasion as a result of disturbance. Examining these interactions may be best achieved through simulation modeling 
(Higgins et al. 1996). Several invasion simulation models have incorporated disturbance into their simulations and found that the effects of disturbance on invasion depends on the vegetation type and the disturbance regime (e.g. Higgins and Richardson 1998; Pausas et al. 2006; Stevens and Beckage 2009; Shackelford et al. 2013). Such modeling efforts have also shown that including feedbacks between fire and vegetation in models can lead to abrupt non-linear state changes (Stevens and Beckage 2009).

Invasive pine species introduced to the Southern Hemisphere are thought to create a positive feedback with fire whereby they alter some aspect of the fire regime which then promotes their own success over native plants (Veblen et al. 2011). Recent work has shown that one of the commonly invading pine species, Pinus contorta, alters fuel loads and structure compared to uninvaded communities and that this likely increases fire spread and severity (Cóbar-Carranza et al. 2014; Taylor et al. 2017; Paritsis et al. 2018). The effect of disturbance on invasion success varies when the likelihood of disturbance differs between uninvaded and invaded areas (Buckley et al. 2007), as is the case for P. contorta invasions into previously fuellimited steppe systems (Veblen et al. 2011; Paritsis et al. 2013). Pinus contorta experiences high levels of fire-induced mortality (Baker 2009), and it recovers rapidly following fire in its native range in western North America (e.g. Turner et al. 1997; Pierce and Taylor 2011; Kemp et al. 2016). However, we have found that in the introduced range, fire only promotes $P$. contorta establishment when the invasion density prior to the fire was high (Taylor et al. 2017). In other words, a positive feedback between pine invasions and fire is likely to form above an invasion density threshold (Taylor et al. 2017).

Given the potential for $P$. contorta to alter fire behavior in invaded systems and to respond differently to fire depending on pre-fire invasion density, it is unknown how fire will 


\section{Methods}

\section{Study Species}

affect invasion success across a site. For example, although fire through a dense invasion will increase the quality of the seedbed and the rate of pine establishment, it may also destroy a large part of the invasion seed source. Given the threshold effect we found, we may expect that fires through a young, low density invasion would reduce post-fire invasion rates, whereas fire through an older, high density invasion would increase invasion rates. Additionally, the invasion threshold at which a positive feedback forms with fire likely depends on the native vegetation.

To explore the interactions between $P$. contorta invasions and fire we created a spatially explicit invasion-fire simulation model. This study aims to answer two questions through simulations with the invasion-fire model. First, will fire through an invaded system promote further invasion and does this depend on the age of the invasion when it burns? Second, will changes in the invasion density threshold that results in increased post-fire $P$. contorta establishment alter invasion density and extent?

We hypothesized that fire early in an invasion would reduce $P$. contorta occupied cells (invasion extent) and mean densities by killing invading trees but not promoting high post-fire establishment rates (due to low pre-fire invasion densities and reproductive output). We expected that fire through older invasions ( $>10$ years, mainly reproductive trees) would result in higher invasion densities, but reduced spatial extent in the short term.

Pinus contorta is native to western North America where its range extends from Yukon Territory, Canada $\left(64^{\circ} \mathrm{N}\right)$ to Baja California, Mexico $\left(31^{\circ} \mathrm{N}\right)$ (Lotan and Critchfield 1990$)$. It is a is a shade-intolerant and fast-growing tree species that first reproduces at 3 to 15 years and produces small seeds capable of long-distance wind dispersal (Richardson et al. 1994; Despain 
2001; Ledgard 2001). There are four varieties of $P$. contorta in its native range that vary morphologically and in their level of serotiny, although serotiny also varies widely within and between populations of the same variety (Lotan and Critchfield 1990). For example, P. contorta var. latifolia generally has higher levels of serotiny than other varieties but the percent of serotinous trees per stand still varies from zero to 100 (Turner et al. 1997; Harvey et al. 2016). $P$. contorta is an obligate seeder with thin bark that experiences high levels of fire-induced

124 mortality (Baker 2009). Stands with high levels of serotiny tend to regenerate with the highest

125 density following fire (Turner et al. 1997), however even non-serotinous P. contorta can

126 regenerate abundantly following fire (Pierce and Taylor 2011; Harvey et al. 2016), likely

127 because $P$. contorta germinates best on bare mineral soil, is a prolific seed producer, exhibits

128 high germination and establishment rates, and benefits from reduced competition with

129 herbaceous species and lower canopy cover following fire (Lotan and Critchfield 1990; Despain

130 2001; Ledgard 2001). Most $P$. contorta seed germinates in the first year and seeds are likely not

131 viable in the seedbank beyond three to four years (Ledgard 2001).

\section{Study Site}

133 Our model simulates a well-studied site in Coyhaique Alto, Chile (CA) (Langdon et al. 2010;

134 Taylor et al. 2016a). CA is a Patagonian steppe site with a cold dry climate dominated by

135 Festuca sp. and cushion plants such as Baccharis sp., Mullinum sp., and Acaena sp. Pine

136 plantations (P. contorta and P. ponderosa) were planted in this area in the late 1980's and $P$.

137 contorta but not $P$. ponderosa has invaded the surrounding native vegetation (Langdon et al.

138 2010; Taylor et al. 2016a). It is unclear which variety of $P$. contorta was planted at this site, but

139 we did not observe serotinous cones on any P. contorta individuals. The probability of fire in 
similar Patagonian steppe sites is low due to limited fuel continuity, however historically there

141 has been anthropogenic burning in the region (Paritsis et al 2013).

\section{$142 \quad$ Simulation Model}

143 We created a spatially explicit cellular automata simulation model in the modeling environment

144 Netlogo (Wilensky 1999) based on the general tree invasion model created by Caplat et al.

145 (2014; Fig. 1). We adapted the tree dynamics of the Caplat et al. (2014) model so that the

146 demographic and dispersal characteristics matched observations for P. contorta (Table 1). We

147 also added fire to the model as described below (Table 2). The dimensions of the modeled

148 landscape (CA) were $1800 \mathrm{~m}$ by $1430 \mathrm{~m}$, divided into $10 \mathrm{~m}$ x $10 \mathrm{~m}$ cells. Simulations ran for 35

149 years. When run without fire to simulate actual conditions at CA, the model performed well

150 compared to field data collected in $27510 \times 10 \mathrm{~m}$ plots in 2012 (Taylor et al. 2016a) and 289

151 10x10 m plots in 2014 (Davis unpublished data; Table 3). Mean observed (in 2014) and

152 simulated (30 model runs) P. contorta density was 11 and 12.9 trees per $100 \mathrm{~m}^{2}$ respectively.

153 Tree Dynamics. The model is composed of a grid where each cell is a cellular-automaton

154 and population dynamics occur within the cell. Each cell was assigned a vegetation type (grass,

155 Nothofagus antarctica, or $P$. contorta plantation) based on a map previously created at CA

156 (Langdon et al. 2010; Taylor et al. 2016a). The plantation started with 15 three-year-old $P$.

157 contorta per cell. Cells outside of the plantation contained no P. contorta at time zero. At each

158 time step (annual) we calculated the number of trees in each individual age class, from the

159 seedbank through 9 years old, within each cell $(10 \mathrm{~m} \times 10 \mathrm{~m}$; see Table 1 for all demographic

160 parameters and their sources). Once trees reached the age of 10 years, they were added to the

161 adult stage class and the total number of adults was tracked. Demographic parameters driving

162 population dynamics were derived from emergence experiments (Langdon 2011), 5 years of

163 monitoring all $P$. contorta individuals in 3 hectares at the Coyhaique Alto site (Pauchard 
164 unpublished data), and a large observational data set from the site (Taylor et al. 2016a).

165 Emergence was lowered by $90 \%$ in cells in which $N$. antarctica was present, based on the 166 extremely low levels of invasion observed in this vegetation type despite its proximity to the 167 plantation (Taylor et al. 2016a). Emergence and survival were also subject to density dependence 168 based on our data and supported by the lack of $P$. contorta regeneration observed beneath $P$. 169 contorta canopies elsewhere in the introduced range (Howell and McAlpine 2016). Seed production was calculated separately for adult trees (age 10 and older) and for trees 171 between the ages of 5 and 9 (hereafter subadults) based on field observations (Table 1). Seed 172 production was determined separately for each cell by drawing a random number of cones per 173 tree from the measured distribution at the Coyhaique Alto site (Taylor et al. 2016a) and 174 multiplying by 20 seeds per cone (Davis unpublished data). For subadults, it was first determined 175 if they were reproductive in a given year or not, based on the proportion of subadults that contained cones in each sampling year at CA; then, the number of cones per tree was drawn from the sampled distribution for subadults. Seeds were dispersed from a cell based on two exponential functions, one for normal 179 dispersal and one for long distance dispersal (Higgins and Cain 2002; Caplat et al. 2008). Each 180 seed had a probability $P_{L D D}$ of being dispersed by the long-distance dispersal function. The 181 majority of seeds were dispersed within 100 meters of the parent tree (Ledgard 2001). We

182 included a separate function for long distance dispersal in the model because long distance 183 dispersal of up to 40 kilometers has been found for P. contorta (Ledgard 2001), a simple 184 exponential model does not capture this long distance dispersal (Nathan and Muller-Landau 185 2000), and long distance dispersal is important in explaining plant invasions and range 186 expansions (Shigesada et al. 1995; Higgins and Richardson 1999). CA experiences consistent 
strong winds and frequent wind events, suggesting that long distance dispersal is important at this site. Our dispersal kernel allowed occasional long-distance dispersal farther than $1 \mathrm{~km}$, although the majority of our long-distance dispersal occurred between 200 and $600 \mathrm{~m}$ from the parent tree. The appropriate parameters for the dispersal functions were determined with a sensitivity analysis that compared the resulting invasion metrics (mean invasion density, maximum invasion density, and mean density at different distances from the plantation edge) to known values sampled at CA. Although we captured mean densities and densities at each

194 distance fairly well, we were less successful in capturing the rare long-distance events that led to establishment of lone trees farther than $500 \mathrm{~m}$ from the plantation edge (Table 3). same cell for each simulation. Given our simulation time of 35 years it is unlikely that more than one fire would burn our study site. Fire spread probabilistically to surrounding cells (Fig. 1) and continued to spread until no new cells were ignited (Perry et al. 2012; Perry et al. 2015). The size of the fires was not fixed but emerged as a function of fire-vegetation-invasion feedbacks. Probability of spread between cells depended on the vegetation type in each cell and was based on the literature for native vegetation (Nothofagus antarctica and steppe; Paritsis et al. 2013) and prior measurements of fuel loads and bareground with different levels of $P$. contorta invasion at CA for invaded cells (Table 2; Taylor et al. 2017). We did not include the effects of topography or wind on fire spread. Given the flat nature of our study site, we do not expect that excluding topography greatly influenced fire spread, however the lack of wind effects in the model could 207 result in smaller fires than might naturally occur. antarctica generally survives and resprouts following fire (Burns 1993). After fire, the 
probability of $P$. contorta establishment increased in $N$. antarctica cells to match the level in the 211 steppe for five years, after which point competition from resprouting $N$. antarctica would likely prevent high $P$. contorta establishment (Burns 1993). Pinus contorta generally establishes well post-fire in its native range (e.g. Turner et al. 1997; Kemp et al. 2016), even where it is not serotinous (e.g. Pierce and Taylor 2011). However, a steppe site in Northern Patagonia showed high post-fire densities only in plots with older, dense pre-fire invasions (Taylor et al. 2017). Given that those $P$. contorta populations (and those at Coyhaique Alto) are not serontinous, we 217 presume the increase in establishment was due to reduced competition with native plants (Taylor 218 et al. 2016b) and enhanced seed bed conditions due to higher fire severity in highly invaded plots 219 (Taylor et al. 2017; Paritsis et al. 2018). Based on these observations that (1) native vegetation 220 seemed to recover and become dominant where pre-fire densities of $P$. contorta were low, and 221 (2) invasion was enhanced when pre-fire pine densities were high, we increased post-fire $P$. contorta establishment in model cells that had a pre-fire invasion density of subadult and adult $P$ contorta greater than a threshold value (Taylor et al. 2017). We found that 10 trees per $100 \mathrm{~m}^{2}$ was the threshold density at a site in Northern Patagonia (Taylor et al. 2017) but we varied the value in the model simulations as described below. The elevated establishment rate in the model, based on pre- and post-fire densities in a steppe site in Northern Patagonia (Taylor et al. 2017), persisted for three years post-fire. We also reduced the seedbank by $50 \%$ in model cells with maximum $P$. contorta age of $>=15$ years based on modeled soil temperatures during fire in different age invasions (Taylor et al. 2017) and the known temperature tolerances of $P$. contorta 230 seeds (Knapp and Anderson 1980). 


\section{Model Scenarios and Statistical Analysis}

To test the effects of fire at different stages of invasion on invasion density and spread, we ran simulations with a single fire ignition for each simulation at five-year intervals (no fire, fire in year 5, year 10, year 15, and year 20). We crossed this fire year treatment with an invasion threshold treatment. We estimated the invasion threshold that increased rates of post-fire $P$. contorta establishment was 10 trees per $100 \mathrm{~m}^{2}$ at a shrub steppe site in Argentinian Patagonia (Taylor et al. 2017). We assessed the effect of changing the P. contorta density threshold on invasion density and extent by including simulations with the invasion threshold set at 5,10 , or 15 trees per $100 \mathrm{~m}^{2}$. We included an invasion threshold treatment because we expect that this threshold may vary by site. Adjusting fire year and invasion threshold left us with a total of 15 treatment combinations ( 5 fire year levels x 3 threshold levels). We ran simulations for 35 years with 100 replicates for each treatment combination (1,500 model runs). We recorded outputs at the end of 35 simulation years for each scenario. Model output included number of burned cells, number of pine-occupied cells, mean pine density in pine-occupied cells, maximum pine density, and maximum distance from the plantation to an invaded cell.

To better explain patterns that emerged from the initial model runs, we also ran the model with each fire year and threshold treatment combination for 35 years and obtained output for each year so that we could determine changes in pine density and number of cells occupied by pine over time. This process was replicated 12 times for each treatment combination.

Model output was analyzed in R (R Core Team 2017) with generalized linear models with fire year and pre-fire invasion density threshold as the explanatory variables and the output as the response. Where necessary (e.g., for number of pine-occupied cells, maximum pine density), a Poisson error distribution fit with quasi-likelihood was used for the models. To 
examine trends over time we used generalized additive mixed models to model mean and maximum pine density, pine-occupied cells and maximum distance from a plantation as a function of the threshold value and the interaction between year and fire year, with model simulation (run) as a random effect. When necessary (e.g., for number of pine-occupied cells, maximum pine density) we used a Poisson error distribution.

\section{Results}

260 Burned Area

Fires that burned in simulation year 5 remained small $(<2000$ cells; Fig. 2$)$ due to the low 262 fuel loads associated with low density pine invasions. Fires in year 10 or 15 had a trimodal 263 distribution with some fires remaining extremely small, while others entered the pine plantation 264 and/or flammable Nothofagus antarctica stands and grew large ( $>2000$ cells; Fig. 2). All fires in 265 year 20 became much larger ( $>4000$ cells) than the fires in year 5 (Fig. 2) due to the presence of 266 large, connected areas of fuel resulting from the high-density of P. contorta.

\section{Effect of Fire Year and Invasion Density Threshold on Invasion}

Overall, the fire year caused significant differences in $P$. contorta invasion response metrics (Fig. 3). In general, fires that occurred late in invasion had the most impact on invasion metrics, causing increases in pine occupancy, maximum pine density, and distance from

271 plantation. Contrary to our expectations, invasion parameters did not decline compared to 272 unburned simulations when fire burned early in the invasion (fire year 5; Fig. 3); fuels were 273 insufficient to carry the fire (Fig. 2) and small fires had little effect on P. contorta mortality. 274 Differences in the pre-fire invasion density threshold that resulted in increased P. contorta establishment post-fire were less important than fire year in explaining invasion density and extent. 
Specifically, fire year, threshold, and their interaction were significant predictors of pineoccupied cells $\left(\chi^{2}=1656.14, \mathrm{df}=4, P<0.001 ; \chi^{2}=39.8\right.$, df $=2, P<0.001 ;$ and $\chi^{2}=54.49$, df $=8$, $P<0.001$ respectively), mean pine density of pine-occupied cells $\left(\mathrm{F}_{4,1485}=1307.3, P<0.001\right.$; $\mathrm{F}_{2,1485}=320.6, P<0.001 ;$ and $\mathrm{F}_{8,1485}=276.9, P<0.001$ respectively), and maximum distance of a pine-occupied cell from the plantation $\left(\mathrm{F}_{4,1485}=362.2, P<0.001 ; \mathrm{F}_{2,1485}=16.4, P<0.001\right.$; and $\mathrm{F}_{8,1485}=7.1, P<0.001$ respectively) after 35 simulation years (Fig. 3). While the number of pineoccupied cells and maximum distance from plantation both increased with increasing fire year, mean density declined. Different pre-fire invasion density thresholds only resulted in different post-fire invasion rates when the fire burned at later invasion stages (Fig. 3). Maximum pine density increased with increasing fire year $\left(\chi^{2}=24125.8, \mathrm{df}=4, P<0.001\right.$; Fig. 3$)$, but was not related to invasion density threshold or the interaction between threshold and fire year $\left(\chi^{2}=2.7\right.$, $\mathrm{df}=2, P=0.25$; and $\chi^{2}=5.5, \mathrm{df}=8, P=0.70$, respectively). The large variability in invasion responses for simulations with fires in year 10 (Fig. 3) can be explained by the size of the fire, with more pine-occupied cells and greater maximum distance from the plantation in the simulations with larger fires (Supplemental information Fig. S1).

\section{Trends Over Time}

The trends over time for all responses (pine-occupied cells, mean pine density, maximum

294 pine density, and maximum distance to plantation) differed between the unburned simulations 295 and those burned in years 10,15 , and 20 ( $P<0.001$ for all comparisons $)$; however, trends over 296 time did not differ between unburned and burned in year 5 ( $P>0.05$ for all responses; Fig. 4). 297 Mean pine density was the only response variable where the invasion density threshold was significant: lower mean densities occurred in simulations with a threshold of 15 than in those with a threshold of $5(P<0.001)$. 
In all treatment combinations, the number of pine-occupied cells jumped significantly in

301 year 8 when the plantation trees matured and increased seed production (Fig. 4). The unburned and fire year 5 simulations indicated that pine-occupied cells and maximum distance to plantation increased steadily after year 8 . With fires in years 10,15 and 20, pine-occupied cells briefly declined the year following fire (Fig. 4). In simulations with fire in years 10 and 15, some runs showed that the fire grew large whereas in others fire size remained small. In runs where the number of burned cells was large, a large jump in pine-occupied cells and maximum distance to plantation occurred as soon as the post-fire cohort became mature and started dispersing seeds (Fig. 4). All fires burned in year 20 became large, due to more continuous pine fuels, and the number of pine- occupied cells and the maximum distance to plantation increased when the post-

310 fire cohort matured (Fig. 4). In all cases, in the years that the number of pine-occupied cells and maximum distance to plantation increased, mean density declined due to lower densities in the front of the invasion wave. Maximum densities peaked at simulation year 17 for the unburned and the fire year 5 simulations. For the other simulations (fire years 10,15 and 20) the maximum density peaked 11 years after fire (Fig. 4) before declining due to the density-dependent feedback on establishment included in the model.

\section{Discussion} necessary to integrate information on disturbance, the local environment, invasive plant traits, and demography (Higgins and Richardson 1998; Buckley et al. 2007; Stevens and Beckage 2009). The model developed in this study is unique in that it combined a mechanistic explanation for feedbacks (altered fuel loads and fire spread) with a population model (Gaertner et al. 2014) to examine the complexity and potential for non-intuitive outcomes resulting from the interaction 
between fire and pine invasions. Although fire was not necessary to initiate a $P$. contorta invasion, simulated fire through invasions that were at least 10 years old increased the spatial extent of pine and its maximum invasion density.

The age of the invasion when the fire occurred proved to be an important parameter, because it affected both the size of the fire and the ability of $P$. contorta to recruit successfully post-fire. The model suggests that the probability of an ignition becoming a large fire increases greatly in older invasions compared with uninvaded steppe sites. Empirical studies show that steppe vegetation is generally fuel limited (Paritsis et al. 2013; Taylor et al. 2017), and pine invasions increase the fuel loads (Taylor et al. 2017; Paritsis et al. 2018), likely resulting in more continuous fire spread. Once fuel levels are sufficient for fire to spread, the pine invasion is generally above the density threshold necessary to cause an increase in $P$. contorta establishment post-fire. This interaction sets up a positive feedback: older, dense invasions promote larger fires which in turn promote denser post-fire invasions that eventually spread more rapidly than invasions in unburned simulations. It is difficult to disentangle the effects of pine density and pine age, given that in the sites used to calibrate the model invasion age and density are strongly positively correlated. However, we would expect the feedback to be weaker where invasions are older but not dense and thus less likely to influence fire behavior due to lower fuel loads. A similar positive feedback between flammable native shrubs and fire occurs in Patagonia (Mermoz et al. 2005), and increasing fire could promote further shifts from fire-sensitive Nothofagus pumilio forests to fire-prone shrublands (Paritsis et al. 2015). Flammable pine plantations (Paritsis et al. 2018), which are often located on the forest-steppe ecotone, and pine invasions, could exacerbate this positive fire feedback and further contribute to losses of fire sensitive Nothofagus species. The situation is particularly acute when plantations are placed 
adjacent to the fire-sensitive Nothofagus pumilio forest, as occurs frequently in the Chilean Aysén Region.

When disturbance is more likely in invaded areas than in uninvaded areas it was

349 predicted that disturbance would decrease invasion rates (Buckley et al. 2007). In contrast, even 350 though fires spread more readily through invaded than uninvaded areas in our simulations, fire 351 increased invasion rates. We attribute this finding to several factors. First, the inherently patchy 352 nature of fires ensures that some mature seed trees survive fires and promote recolonization of 353 the burned area (Pierce and Taylor 2011). Second, P. contorta seeds can withstand high 354 temperatures in the soil (Knapp and Anderson 1980; Cóbar-Carranza et al. 2015), and these 355 temperatures generally exceed modeled soil temperatures in fire simulations that are based on 356 fuel loads recorded at four sites with P. contorta invasions (Taylor et al. 2017). For that reason, 357 rapid regeneration of pine could come from an in-situ post-fire seedbank (although P. contorta 358 seeds generally only survive one to three years in the soil seedbank (Ledgard 2004)). Third, $P$. 359 contorta reproduces at a young age, particularly in its introduced range (Taylor et al. 2016a).

360 We found that invasion was only slowed for 5 years post-fire until a new cohort became 361 reproductive. The post-fire cohort was denser than invasions in unburned simulations, allowing 362 the invasion to proceed more quickly than in the unburned simulations. In general, the benefits of disturbance for establishment rates outweighed the negative 364 effects of disturbance on tree survival in our model experiment. However, the tradeoff between 365 pine mortality and increased post-fire establishment rates can be seen by comparing the number 366 of occupied cells when fire burned in year 10 versus year 20 (Figs. 3 \& S1). The highest number 367 of pine occupied cells occurred when a large fire burned in year 10 (Fig. S1). These fires tended 368 to be smaller than fires burned in year 20, thus the adult mortality rate was lower, but enough 
cells burned that had high invasion densities to also result in increased establishment rates at some locations on the landscape. Therefore, a slight effect of reducing the adult population that provides a seed source was observed. The fires in our simulation were fairly patchy leaving enough adults on the landscape to provide a seed source. We expect that where large patches of complete adult mortality occur, seed limitation may slow recolonization of the burned area as has been observed for non-serotinous populations of $P$. contorta in its native range (Harvey et al. 2016).

It has long been known that fire and other disturbances promote pine invasions, particularly for serotinous species (Richardson and Bond 1991; Richardson and Higgins 1998); however, it has also been recognized that the effects of disturbance are context specific (D'Antonio 2000). In the case of invasive species, disturbance must be understood in light of the native vegetation and disturbance regime as well as the plant traits of the invader (Higgins and Richardson 1998). We suggest that $P$. contorta invasion will be promoted by fire across much of the world, based on several factors: first, changing the pre-fire invasion pine density (threshold) necessary to promote establishment of pine after a fire had a minimal effect on model outcomes. Thus, even if critical levels of pine density vary by site, the response of pine invasion after fire will not show significant variation. Second, our intermediate threshold level (1000 trees/ha) was estimated from a site with fire-adapted species that readily resprout after fire

387 (Nuñez and Raffaele 2007). We would expect the threshold to be even lower in sites with less 388 fire-adapted vegetation (e.g., New Zealand, Perry et al. 2014) because reduced recovery of native 389 vegetation after fire would decrease competition with pine seedlings. Additionally, sites with less

390 fire-adapted vegetation are particularly vulnerable to human-induced changes in fire regimes

391 (Perry et al. 2014; Whitlock et al. 2015). Third, P. contorta growth is slower at the Chilean 
Coyhaique Alto site than at other sites in Argentina and New Zealand where P. contorta is also currently invading (Taylor et al. 2016a). Thus, fuel accumulation with invasion is more rapid in these other sites suggesting that a positive feedback could form earlier in the invasion. Fourth, $P$. contorta individuals also have higher fecundity at a younger age at other sites in Argentina and New Zealand than at Coyhaique Alto (Taylor et al. 2016a). Therefore, the post-fire cohort of pine will become reproductive sooner and produce more seeds, promoting an even larger increase in post-fire invasion spread rates. Finally, the $P$. contorta at the study sites used to parameterize the model were not serotinous (Taylor et al. 2016a; Taylor et al. 2017). We would expect $P$. contorta to be even more abundant following fire where there are serotinous individuals (Turner et al. 1997).

Our study site in Coyhaique Alto was relatively homogenous in terms of suitable habitat for $P$. contorta but in sites with more heterogeneous habitat, spread rates will depend on other factors, including density dependence (Pachepsky and Levine 2011) and background habitat suitability for establishment, survival, and reproduction. Furthermore, interactions with other invasive species that also respond positively to fire may reduce $P$. contorta establishment rates post-fire. For example, initial observations following a fire that burned dense $P$. contorta invasions in New Zealand suggest that abundant regrowth of several invasive European pasture grasses, and potentially post-fire climate conditions, may have limited $P$. contorta establishment in the first three years following fire (Davis unpublished data). Abiotic conditions may also affect feedbacks. For example, high densities of pines were found after fire in Northern Patagonia in wet but not dry sites (Raffaele et al. 2016). Thus, the potential for fire to promote pine invasions will likely depend strongly on the response of the dominant vegetation to fire, as well as other site-specific factors such as climate. 

several patterns seen in the snapshot results from year 35 (Fig. 3). Mean density declined when the number of pine- occupied cells increased due to an increase in low-density cells at the invasion front. Density dependence caused the overall mean density to remain fairly constant between fire year treatments, after an initial brief increase in mean pine density post-fire in the later year burns. However, the maximum density was significantly higher in simulations with

421 large fires. High maximum pine densities will likely result in strong declines in native plant 422 cover and richness, which are both negatively correlated with $P$. contorta cover (Taylor et al. 423 2016b). Therefore, synergies between disturbance and invasion may accelerate impacts due to $P$. 424 contorta invasion on native ecosystems.

Our modeling experiments indicate that high maximum densities of $P$. contorta after fire abruptly increased the number of pine-occupied cells and the maximum distance of invasion 427 from plantations. This stepwise invasion process with rapid and nonlinear increases in spread rates contrasts with unburned and small fire (fire year 5 and some fire year 10) simulations where the increase in occupied cells was linear after the initial jump in year 8 (Fig. 4). Other studies

430 have also found that feedbacks between tree invasions and fire led to nonlinear behavior (Stevens 431 and Beckage 2009) and thus rapid increases in tree invasions may be expected in other systems 432 that also have feedbacks between invasion and fire.

433 Our results highlight the necessity of managing pine invasions before they reach an

434 advanced stage where positive feedbacks between fire and pine invasion could lead to dramatic 435 increases in invasion rate. The increasing density and extent of post-fire pine will exacerbate 436 non-fire driven invasion impacts, such as declines in native biodiversity (Ledgard and Paul 2008; 437 Pawson et al. 2010; Taylor et al. 2016b), changes in soil microbial communities and nutrient 
cycling (Dehlin et al. 2008; Dickie et al. 2014), and altered hydrological regimes (Farley et al. 2005; Fernandez et al. 2009). Pine plantations in Patagonia became widespread beginning in the 1970s, while pine plantations were already widespread by that point in South Africa, Australia, and New Zealand (Simberloff et al. 2010). Therefore, many pine invasions across the Southern Hemisphere are likely at the stage where fire will promote invasion. Fires in the study region, and other parts of the Southern Hemisphere with introduced pines (South Africa, southeast Australia, and New Zealand), are predicted to increase in the future given climate trends and changes in land use (Veblen et al. 2008; Holz and Veblen 2011; Veblen et al. 2011; Moritz et al. 2012). Large fires in pine plantations in the study region (near Coyhaique, Chile in 2016) and in other regions invaded by $P$. contorta (Craigieburn, New Zealand 2015) occurred during recent warmer-than-average summers, which underpins the need to seriously consider the potential impact of wildfires on pine plantations and invasions. While fire is not necessary to promote pine invasions, it could certainly increase the invasion rate and further complicate management efforts going into the future.

\section{Acknowledgements}

KTD and BDM were funded by NSF-WildFIRE PIRE, OISE 09667472.

\section{References}

Baker WL (2009) Fire Ecology in Rocky Mountain Landscapes. Island Press, Washington D.C. Balch JK, Bradley BA, D'Antonio CM, Gomez-Dans J (2013) Introduced annual grass increases regional fire activity across the arid western USA (1980-2009). Glob Change Biol 19: $173-183$ 
Brooks ML, D'Antonio CM, Richardson DM, Grace JB, Keeley JE, DiTomaso JM, Hobbs RJ, Pellant M, Pyke D (2004) Effects of invasive alien plants on fire regimes. Bioscience 54: 677-688

Buckley YM, Bolker BM, Rees M (2007) Disturbance, invasion and re-invasion: managing the weed-shaped hole in disturbed ecosystems. Ecol Lett 10: 809-817

Burns BR (1993) Fire-induced dynamics of Araucaria araucana - Nothofagus antartica forest in the Southern Andes. J Biogeogr 20: 669-685

Caplat P, Anand M, Bauch C (2008) Symmetric competition causes population oscillations in an individual-based model of forest dynamics. Ecol Model 211: 491-500

Caplat P, Hui C, Maxwell BD, Peltzer DA (2014) Cross-scale management strategies for optimal control of trees invading from source plantations. Biol Invasions 16: 677-690

Cóbar-Carranza AJ, García RA, Pauchard A, Peña E (2014) Effect of Pinus contorta invasion on forest fuel properties and its potential implications on the fire regime of Araucaria araucana and Nothofagus antarctica forests. Biol Invasions 16: 2273-2291

Cóbar-Carranza AJ, García RA, Pauchard A, Peña E (2015) Effects of high temperatures in the germination and seed survival of the invasive species Pinus contorta and two native species of South Chile. Bosque 36: 53-60

D'Antonio MC (2000) Fire, plant invasions, and global changes. In: Mooney HA, Hobbs RJ (ed) Invasive Species in a Changing World. Island Press, Washington D.C., pp 65-93

Davis MA, Grime JP, Thompson K (2000) Fluctuating resources in plant communities: a general theory of invasibility. J Ecol 88: 528-534 
Dehlin H, Peltzer DA, Allison VJ, Yeates GW, Nilsson MC, Wardle DA (2008) Tree seedling performance and below-ground properties in stands of invasive and native tree species. $\mathrm{N}$

$$
\text { Z J Ecol 32: 67-79 }
$$

Despain DG (2001) Dispersal ecology of lodgepole pine (Pinus contorta Dougl.) in its native environment as related to Swedish forestry. For Ecol Manag 141:59-68

Dickie IA, St John MG, Yeates GW, Morse CW, Bonner KI, Orwin K, Peltzer DA (2014) Belowground legacies of Pinus contorta invasion and removal result in multiple mechanisms of invasional meltdown. AoB Plants 6: plu056

Farley KA, Jobbagy EG, Jackson RB (2005) Effects of afforestation on water yield: a global synthesis with implications for policy. Glob Change Biol 11: 1565-1576

Fernandez ME, Gyenge J, Schlichter T (2009) Water flux and canopy conductance of natural versus planted forests in Patagonia, South America. Trees 23: 415-427

Gaertner M, Biggs R, Te Beest M, Hui C, Molofsky J, Richardson DM (2014) Invasive plants as drivers of regime shifts: identifying high-priority invaders that alter feedback relationships. Divers Distributions 20: 733-744

Harvey BJ, Donato DC, Turner MG (2016) High and dry: post-fire tree seedling establishment in subalpine forests decreases with post-fire drought and large stand-replacing burn patches. Glob Ecol Biogeogr 25: 655-669

Higgins SI, Cain ML (2002) Spatially realistic plant metapopulation models and the colonization-competition trade-off. J Ecol 90: 616-626

Higgins SI, Richardson DM (1998) Pine invasions in the southern hemisphere: modelling interactions between organism, environment and disturbance. Plant Ecol 135: 79-93 
502

503

504

505

506

507

508

509

510

511

512

513

514

515

516

517

518

519

520

521

522

Higgins SI, Richardson DM (1999) Predicting plant migration rates in a changing world: The role of long-distance dispersal. Am Nat 153: 464-475

Higgins SI, Richardson DM, Cowling RM (1996) Modeling invasive plant spread: The role of plant-environment interactions and model structure. Ecol 77: 2043-2054

Holz A, Veblen TT (2011) Variability in the Southern Annular Mode determines wildfire activity in Patagonia. Geophys Res Lett 38: L14710

Howell CJ, McAlpine KG (2016) Native plant species richness in non-native Pinus contorta forest. N Z J Ecol 40: 131-136

Johnstone IM (1986) Plant invasion windows - a time-based classification of invasion potential. Biol Rev Camb Philos Soc 61: 369-394

Kemp KB, Higuera PE, Morgan P (2016) Fire legacies impact conifer regeneration across environmental gradients in the U.S. northern Rockies. Landscape Ecol 31: 619-636

Knapp AK, Anderson JE (1980) Effect of heat on germination of seeds from serotinous lodgepole pine cones. Am Midl Nat 104: 370-372.

Langdon B (2011) Invasión de Pinus contorta Doug. ex Loud. en la Patagonia Chilena: patrones y mecanismos tras el proceso. Facultad de Ciencias Forestales. Universidad de Concepción, Concepción, Chile

Langdon B, Pauchard A, Aguayo M (2010) Pinus contorta invasion in the Chilean Patagonia: local patterns in a global context. Biol Invasions 12: 3961-3971

Ledgard N (2001) The spread of lodgepole pine (Pinus contorta, Dougl.) in New Zealand. Forest Ecol Manag 141: 43-57. 
Ledgard NJ (2004) Wilding conifers - New Zealand history and research background. In: Hill RL, Zydenbos SM, Bezar CM (ed). Managing wilding conifers in New Zealand - present and future. New Zealand Plant Proetction Society Inc, Christchurch.

Ledgard NJ, Paul TSH (2008) Vegetation successions over 30 years of high country grassland invasion by Pinus contorta. N Z J Plant Protection 61: 98-104

Lotan JE, Critchfield WB (1990) Pinus contorta Dougl. ex. Loud. lodgepole pine. In: Burns RM, Honkala BH (ed) Silvics of North America, Volume 1 Conifers. USDA Forest Service, Washington, DC, pp 302-315.

Mack MC, D'Antonio CM (1998) Impacts of biological invasions on disturbance regimes. Trends Ecol Evol 13: 195-198

Mermoz M, Kitzberger T, Veblen TT (2005) Landscape influences on occurrence and spread of wildfires in Patagonian forests and shrublands. Ecol 86:2705-2715

Moritz MA, Parisien MA, Batllori E, Krawchuk MA, Van Dorn J, Ganz DJ, Hayhoe K (2012) Climate change and disruptions to global fire activity. Ecosphere 3: 1-22

Nathan R, Muller-Landau HC (2000) Spatial patterns of seed dispersal, their determinants and consequences for recruitment. Trends Ecol Evol 15: 278-285

Nuñez MA, Raffaele E (2007) Afforestation causes changes in post-fire regeneration in native shrubland communities of northwestern Patagonia, Argentina. J Veg Science 18:827-834

Pachepsky E, Levine JM (2011) Density dependence slows invader spread in fragmented landscapes. Am Nat 177: 18-28

Paritsis J, Holz A, Veblen TT, Kitzberger T (2013) Habitat distribution modeling reveals vegetation flammability and land use as drivers of wildfire in SW Patagonia. Ecosphere 4: $1-20$ 
Paritsis J, Landesmann JB, Kitzberger T, Tiribelli F, Sasal Y, Quintero C, Dimarco RD, BarriosGarcia MN, Iglesias AL, Diez JP, Sarasola M, Nuñez MA (2018) Pine plantations and invasion alter fuel structure and potential fire behavior in a Patagonian forest-steppe ecotone. Forests 9: 117

Paritsis J, Veblen TT, Holz A (2015) Positive fire feedbacks contribute to shifts from Nothofagus pumilio forests to fire-prone shrublands in Patagonia. J Veg Science 26: 89-101

Pauchard A, Garcia RA, Peña E, Gonzalez C, Cavieres LA, Bustamante RO (2008) Positive feedbacks between plant invasions and fire regimes: Teline monspessulana (L.) K. Koch (Fabaceae) in central Chile. Biol Invasions 10: 547-553

Pausas JG, Lloret F, Vila M (2006) Simulating the effects of different disturbance regimes on Cortaderia selloana invasion. Biol Conserv 128: 128-135

Pawson SM, McCarthy JK, Ledgard NJ, Didham RK (2010) Density-dependent impacts of exotic conifer invasion on grassland invertebrate assemblages. J Appl Ecol 47: 10531062

Perry GLW, Wilmshurst JM, McGlone MS (2014) Ecology and long-term history of fire in New Zealand. N Z J Ecol 38: 157-176

Perry GLW, Wilmshurst JM, McGlone MS, McWethy DB, Whitlock C (2012) Explaining firedriven landscape transformation during the Initial Burning Period of New Zealand's prehistory. Glob Change Biol 18: 1609-1621

Perry GLW, Wilmshurst JM, Ogden J, Enright NJ (2015) Exotic mammals and invasive plants alter fire-related thresholds in southern temperate forested landscapes. Ecosystems 18: 1290-1305 
Pierce AD, Taylor AH (2011) Fire severity and seed source influence lodgepole pine (Pinus contorta var. murrayana) regeneration in the southern cascades, Lassen volcanic National Park, California. Landscape Ecol 26: 225-237

R Core Team (2017) R: A Language and Environment for Statistical Computing version 3.3.3. Vienna, Austria: R Foundation for Statistical Computing.

Raffaele E, Nuñez MA, Enestrom J, Blackhall M (2016) Fire as mediator of pine invasion: evidence from Patagonia, Argentina. Biol Invasions 18: 597-601

Richardson DM, Bond WJ (1991) Determinants of plant distribution - Evidence from pine invasions. Am Nat 137: 639-668

Richardson DM, Cowling RM (1992) Why is mountain fynbos invasible and which species invade? In: van Wilgen BW, Richardson DM, Kruger FJ, van Hensbergen HJ (ed) Fire in South African Mountain Fynbos. Springer, Berlin, pp 161-181

Richardson DM, Higgins SI. 1998. Pines as invaders in the southern hemisphere. In: Richardson DM (ed) Ecology and Biogeography of Pinus. Cambridge University Press, Cambridge, pp $450-473$

Richardson DM, Williams PA, Hobbs RJ (1994) Pine invasion in the Southern Hemisphere: determinants of spread and invadability. J Biogeogr 21: 511-527

Rossiter NA, Setterfield SA, Douglas MM, Hutley LB (2003) Testing the grass-fire cycle: alien grass invasion in the tropical savannas of northern Australia. Divers Distributions 9: 169176

Shackelford N, Renton M, Perring MP, Hobbs RJ (2013) Modeling disturbance-based native invasive species control and its implications for management. Ecol Appl 23: 1331-1344. 
Sher AA, Hyatt LA (1999) The disturbed resource-flux invasion matrix: a new framework for patterns of plant invasion Biol Invasions 1: 107-114

Shigesada N, Kawasaki K, Takeda Y (1995) Modeling stratified diffusion in biological invasions. Am Nat 146: 229-251

Simberloff D, Nuñez MA, Ledgard NJ, Pauchard A, Richardson DM, Sarasola M, Van Wilgen BW, Zalba SM, Zenni RD, Bustamante R, Peña E, Ziller SR (2010) Spread and impact of introduced conifers in South America: Lessons from other southern hemisphere regions. Austral Ecol 35: 489-504

Stevens JT, Beckage B (2009) Fire feedbacks facilitate invasion of pine savannas by Brazilian pepper (Schinus terebinthifolius). New Phytol 184: 365-375.

Taylor KT, Maxwell BD, McWethy DB, Pauchard A, Nunez MA, Whitlock C (2017) Pinus contorta invasions increase wildfire fuel loads and may create a positive feedback with fire. Ecology 98: 678-687

Taylor KT, Maxwell BD, Pauchard A, Nuñez MA, Peltzer DA, Terwei A, Rew LJ (2016a) Drivers of plant invasion vary globally: evidence from pine invasions within six ecoregions. Glob Ecol Biogeogr 25: 96-106

Taylor KT, Maxwell BD, Pauchard A, Nuñez MA, Rew LJ (2016b) Native versus non-native invasions: similarities and differences in the biodiversity impacts of Pinus contorta in introduced and native ranges. Divers Distributions 22: 578-588

Turner MG, Romme WH, Gardner RH, Hargrove WW (1997) Effects of fire size and pattern on early succession in Yellowstone National Park. Ecol Monograph 67: 411-433. 
van Wilgen BW, Richardson DM (1985) The effects of alien shrub invasions on vegetation structure and fire behavior in South African fynbos shrublands: A simulation study. $\mathrm{J}$ Appl Ecol 22: 955-966

Veblen TT, Holz A, Paritsis J, Raffaele E, Kitzberger T, Blackhall M (2011) Adapting to global environmental change in Patagonia: What role for disturbance ecology? Austral Ecol 36: 891-903.

Veblen TT, Kitzberger T, Raffaele E, Mermoz M, Conzalez ME, Sibold JS, Holz A (2008) The historical range of variability of fires in the Andean-Patagonian Nothofagus forest region. Int J Wildland Fire 17: 724-741

Whitlock C, McWethy DB, Tepley AJ, Veblen TT, Holz A, McGlone MS, Perry GLW, Wilmshurst JM, Wood SW (2015) Past and present vulnerability of closed-canopy temperate forests to altered fire regimes: a comparison of the Pacific Northwest, New Zealand, and Patagonia. Bioscience 65: 151-163.

Wilensky U (1999) NetLogo. http://ccl.northwestern.edu/netlogo/. Center for Connected Learning and Computer-Based Modeling, Northwestern University, Evanston, IL Zalba SM, Cuevas YA, Boo RM (2008) Invasion of Pinus halepensis Mill. following a wildfire in an Argentine grassland nature reserve. J Environ Manage 88: 539-546. 
634 Table 1. Model demographic parameters and their sources.

\begin{tabular}{|c|c|c|}
\hline Parameter & Value & Description \& Source \\
\hline $\begin{array}{l}\text { Plantation } \\
\text { density }\end{array}$ & $\begin{array}{l}15 \text { trees per } \\
100 \mathrm{~m}^{2}\end{array}$ & $\begin{array}{l}\text { Pauchard communication with forestry company } \\
\text { that owns plantation }\end{array}$ \\
\hline Dispersal & $\begin{array}{l}\text { Alpha }=3.5 \\
\text { beta }=0.0035 \\
\text { C }=50 \\
\text { pLDD }=0.1\end{array}$ & $\begin{array}{l}\text { Alpha, beta, C are dispersal parameters and pLDD } \\
\text { is probability of long distance dispersal (LDD). } \\
\text { Sensitivity analysis described in methods }\end{array}$ \\
\hline pEst & 0.01 & $\begin{array}{l}\text { Probability of establishment } \\
\text { Langdon } 2011\end{array}$ \\
\hline $\begin{array}{l}\text { pEst in } \\
\text { NOAN }\end{array}$ & $0.1 * \mathrm{pEst}$ & $\begin{array}{l}\text { pEst in N. antarctica (NOAN) plots } \\
\text { Taylor et al. } 2016 \mathrm{a}\end{array}$ \\
\hline $\mathrm{S}_{12}$ & 0.9 & $\begin{array}{l}\text { Survival year } 1 \text { to } 2 \\
\text { Pauchard unpublished data }\end{array}$ \\
\hline $\begin{array}{l}\mathrm{S}_{23}, \mathrm{~S}_{34}, \mathrm{~S}_{45} \\
\mathrm{~S}_{56}\end{array}$ & 0.97 & $\begin{array}{l}\text { Survival year } 2 \text { to } 3 \text { up to survival year } 5 \text { to } 6 \\
\text { Pauchard unpublished data }\end{array}$ \\
\hline $\begin{array}{l}\mathrm{S}_{67}, \mathrm{~S}_{78}, \mathrm{~S}_{89} \\
\mathrm{~S}_{9 \mathrm{~A}}, \mathrm{~S}_{\mathrm{AA}}\end{array}$ & 0.99 & $\begin{array}{l}\text { Survival year } 6 \text { to } 7 \text { up to adult survival } \\
\text { Pauchard unpublished data }\end{array}$ \\
\hline $\begin{array}{l}\text { Seedbank } \\
\text { survival }\end{array}$ & 0.2 & $\begin{array}{l}\text { Proportion of seeds surviving each year } \\
\text { Ledgard } 2004\end{array}$ \\
\hline $\begin{array}{l}\text { Seed } \\
\text { predation }\end{array}$ & 0.03 & $\begin{array}{l}\text { Proportion of seeds removed by predators } \\
\text { Davis unpublished data }\end{array}$ \\
\hline $\begin{array}{l}\text { Adult cones } \\
\text { per tree }\end{array}$ & $\begin{array}{l}\text { Mean: } 38 \\
\text { sd: } 20\end{array}$ & $\begin{array}{l}\text { Adult cones per tree mean and standard deviation } \\
\text { Taylor et al. } 2016 \mathrm{a}\end{array}$ \\
\hline Prepro & 0.28 & $\begin{array}{l}\text { Probability a subadult (ages 5-9) has cones in given } \\
\text { year } \\
\text { Taylor et al. } 2016 \mathrm{a}\end{array}$ \\
\hline $\begin{array}{l}\text { Subadult } \\
\text { cones per tree }\end{array}$ & $\begin{array}{l}\text { Mean: 9.5; } \\
\text { sd: } 8\end{array}$ & $\begin{array}{l}\text { Subadult cones per tree mean and standard } \\
\text { deviation } \\
\text { Taylor et al. 2016a }\end{array}$ \\
\hline$f_{A}, f_{S A}$ & Cones $* 20$ & $\begin{array}{l}\text { Seeds per cone for adult and subadult trees } \\
\text { Davis unpublished data }\end{array}$ \\
\hline
\end{tabular}


642 Table 2. Fire-related model parameters and their sources.

\begin{tabular}{|c|c|c|}
\hline Parameter & Value & Description \& Source \\
\hline $\begin{array}{l}\text { Invasion density } \\
\text { threshold }(P . \text { contorta } \\
\left.\text { per } 100 \mathrm{~m}^{2}\right)\end{array}$ & $5,10,15$ & $\begin{array}{l}\text { Pre-fire density above which } \\
P . \text { contorta establishment is } \\
\text { increased post-fire for } 3 \text { years. } \\
\text { Taylor et al. } 2017\end{array}$ \\
\hline $\begin{array}{l}\text { Post-fire establishment in } \\
\text { plots above invasion } \\
\text { density threshold }\end{array}$ & $\begin{array}{l}0.043 \text { for } 3 \text { years post- } \\
\text { fire }\end{array}$ & Taylor et al. 2017 \\
\hline $\begin{array}{l}\text { Post-fire establishment in } \\
\text { N. antarctica plots }\end{array}$ & $\begin{array}{l}\text { pEst }(0.01) \text { for first } 5 \text { yrs } \\
\text { post-fire }\end{array}$ & $\begin{array}{l}\text { Same as steppe plots because } \\
\text { fire reduces competition with } \\
\text { N. antarctica until it recovers } \\
\text { Burns } 1993\end{array}$ \\
\hline $\begin{array}{l}\text { Seedbank }(\mathrm{sb}) \text { response } \\
\text { to fire }\end{array}$ & $\begin{array}{l}\mathrm{Sb}=\mathrm{sb}^{*} 0.5 \text { if maximum } \\
\text { tree age }>15 \text { years } \\
\mathrm{Sb}=\mathrm{sb} \text { otherwise }\end{array}$ & $\begin{array}{l}\text { Taylor et al. } 2017 \\
\text { Knapp \& Anderson } 1980\end{array}$ \\
\hline $\begin{array}{l}\text { Probability fire spread in } \\
P . \text { contorta }\end{array}$ & $\begin{array}{l}\text { If density }>40 \text { or } \\
\text { oldest tree }>10 \text { years } \\
\text { spread prob. }=0.8 \\
\text { Otherwise }=\text { spread in } \\
\text { that vegetation type } \\
(\text { steppe or N. antarctica) }\end{array}$ & Taylor et al. 2017 \\
\hline $\begin{array}{l}\text { Probability fire spread in } \\
\text { N. antarctica }\end{array}$ & 0.61 & Paritsis et al. 2013 \\
\hline $\begin{array}{l}\text { Probability fire spread in } \\
N \text {. antarctica } \text { with steppe } \\
\text { neighbors }\end{array}$ & 0.71 & $\begin{array}{l}\text { Higher probably of burning } \\
\text { due to drying effect of edge } \\
\text { with steppe }\end{array}$ \\
\hline $\begin{array}{l}\text { Probability fire spread in } \\
N \text {. antarctica with } P \text {. } \\
\text { contorta neighbors older } \\
\text { than } 10 \text { years }\end{array}$ & 0.71 & $\begin{array}{l}\text { Higher probably of burning } \\
\text { when next to mature lodgepole }\end{array}$ \\
\hline $\begin{array}{l}\text { Probability fire spread in } \\
\text { steppe }\end{array}$ & 0.3 & $\begin{array}{l}\text { Paritsis et al. } 2013 \\
\text { Taylor et al. } 2017\end{array}$ \\
\hline
\end{tabular}


649 Table 3. Observed (Taylor et al. 2016a) and simulated (30 runs, no fire) pine invasion metrics for 650 the Coyhaique Alto site. For the simulation the mean and the standard deviation (SD) from the 65130 runs for each invasion metric is shown. Densities are in units of trees per $100 \mathrm{~m}^{2}$. "Occupied 652 plots $0-100 \mathrm{~m}$ " refers to plots with at least one $P$. contorta individual at distances of 0-100 m 653 from the plantation edge.

\begin{tabular}{lrrrr}
\hline & Observed & Observed & \multicolumn{2}{c}{ Simulation } \\
& 2012 & 2014 & Mean & SD \\
\hline Plantation age & 24 & 26 & 26 & - \\
Mean density of pine-occupied cells & 10.1 & 11.0 & 12.86 & 0.10 \\
Mean adult pine density in cells with adults & - & 5.0 & 4.88 & 0.08 \\
Farthest invaded cell (m from plantation) & 901 & 901 & 459.02 & 18.83 \\
Mean density in Nothofagus cells occupied & & & & \\
by at least one P. contorta & 1.6 & 2.0 & 2.24 & 0.22 \\
Maximum P. contorta density & 83 & 67 & 36.43 & 1.68 \\
Mean pine density occupied plots 0-100 m & 28.1 & 19.9 & 22.29 & 0.15 \\
Mean pine density occupied plots 100-200 m & 16.6 & 25.2 & 10.79 & 0.13 \\
Mean pine density occupied plots 200-300 m & 4.1 & 5.9 & 7.13 & 0.52 \\
Mean pine density occupied plots 300-400 m & 3.6 & 4.9 & 4.02 & 0.45 \\
Mean pine density occupied plots 400-500 m & 1.8 & 2.8 & 1.31 & 0.24 \\
\hline
\end{tabular}

654

655

656

657

658

659

660 


\section{Figure captions}

662 Figure 1. Diagram of the model flow. Abbreviations are explained in Tables 1 and 2, except

$663 \mathrm{n}$ (adults) which signifies the number of adults in a cell. This variable affects establishment and

664 survival at some stages through density dependence.

665 Figure 2. Frequency of fire size (number of burned cells) by fire year treatment (unburned and

666 burned in years $5,10,15$, or 20 of the invasion) during $P$. contorta simulated invasion. The

667 number of simulations run for each fire year treatment was constant (300).

668 Figure 3. Simulation results for (A) number of $P$. contorta occupied cells; (B) mean pine density

669 in occupied cells $\left(100 \mathrm{~m}^{2}\right)$; (C) maximum pine density (trees per $\left.100 \mathrm{~m}^{2}\right)$; and (D) maximum

670 distance of a pine-invaded cell from the plantation for the five fire year treatments (unburned and

671 burned in years $5,10,15$, or 20 of the invasion). Number of pine-occupied cells and their

672 densities exclude cells in the plantation. Colors show three different threshold densities for $P$.

673 contorta (number of trees per $100 \mathrm{~m}^{2}$ cell) prior to fire. Exceeding these threshold densities was

674 required to increase $P$. contorta establishment post-fire.

675 Figure 4. Time series show changes in plot parameters over the course of the model simulation:

676 (A) Change in P. contorta occupied cells; (B) mean density of pine-occupied cells: (C)

677 maximum ( $\max$ ) pine density; and (D) maximum distance of an invaded cell from the plantation

678 over simulation time. Densities are in units of trees per cell $\left(100 \mathrm{~m}^{2}\right)$. Smooth lines are predicted

679 trends from the GAMM model. There was no statistical difference in the relationship between

680 year and occupied cells for the unburned and fire year 5 simulations so only one line is shown

681 (black). Colored lines and points represent simulations burned in year 10 (blue), 15 (yellow), and

68220 (green) of the invasion. Note that the line for fire year 10 does not appear to match the data

683 because some points from fire year 10 simulations are hidden behind other points and represent

684 the simulations where fires remained small. 


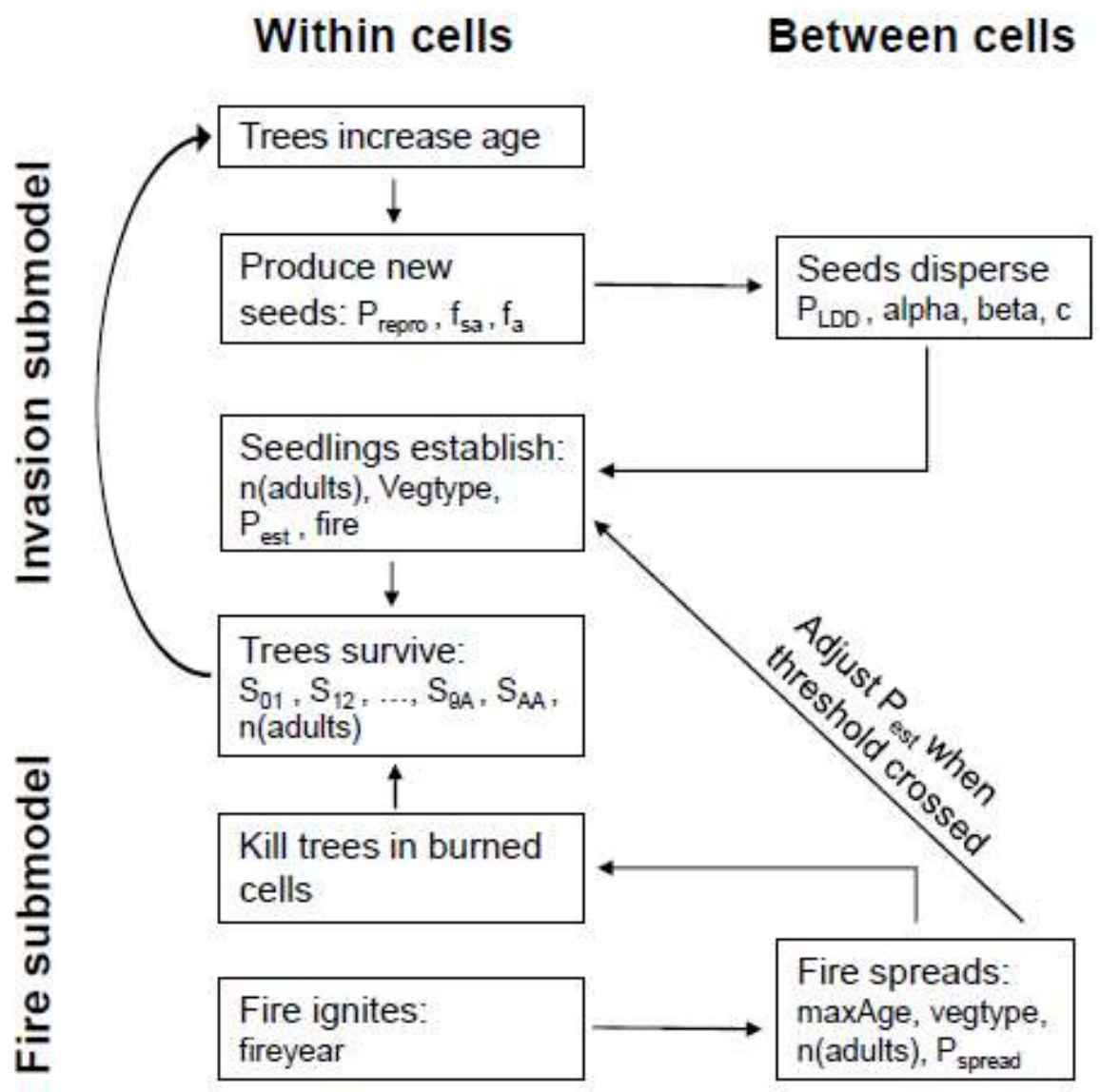

686 
Figure 2.

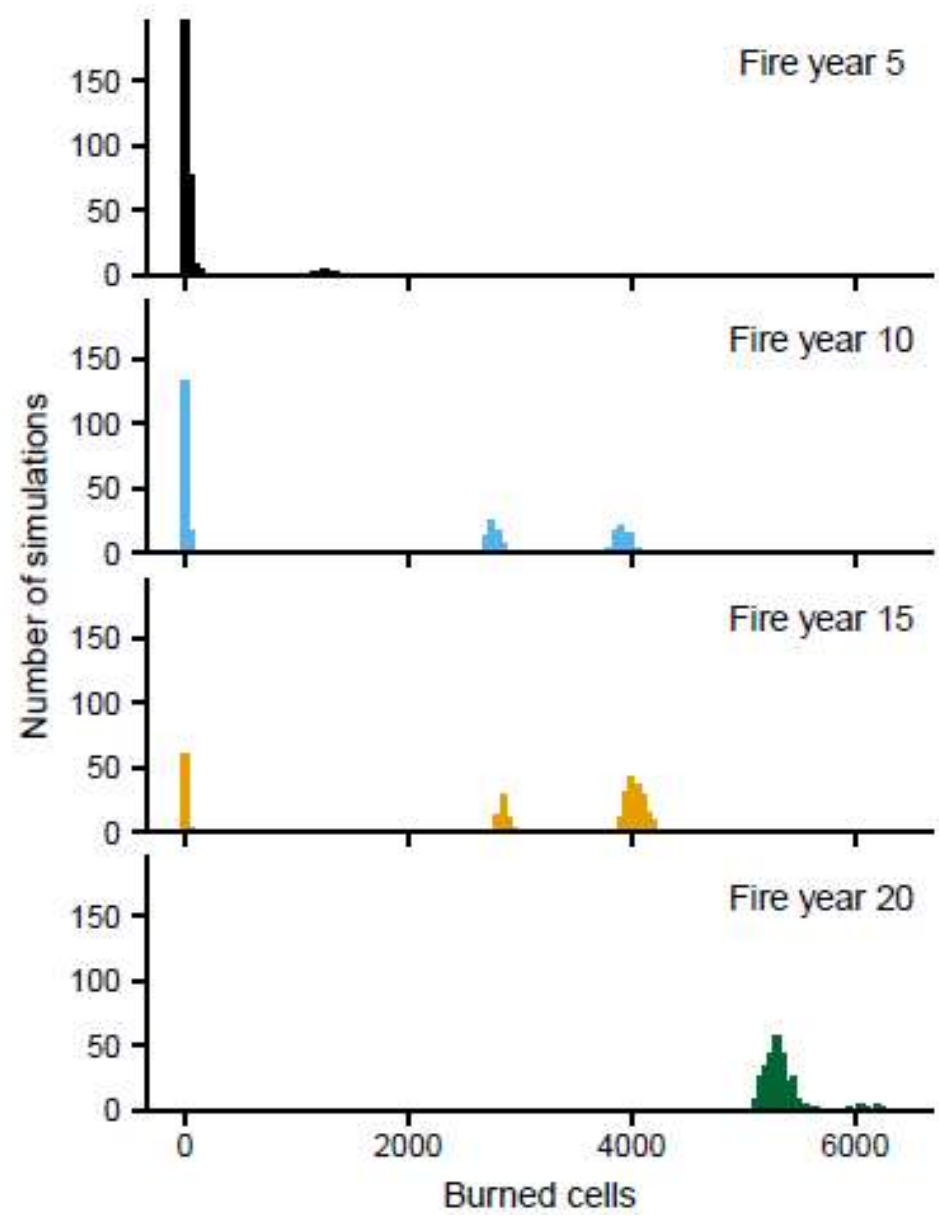

697

698

699

700

701

702

703

704

705

706 
$707 \quad$ Figure 3.
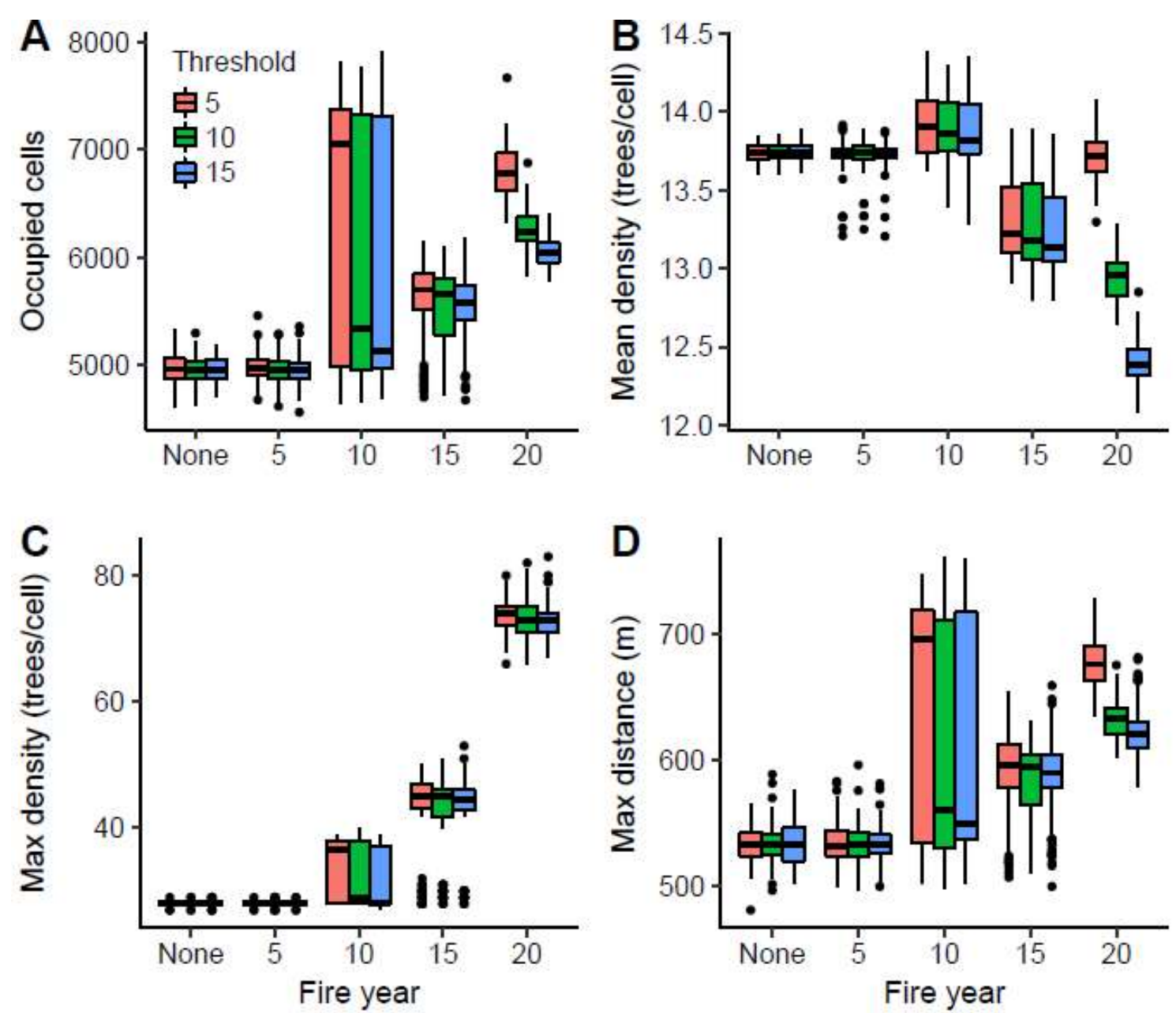

709

710

711

712

713

714

715

716 
717 Figure 4.

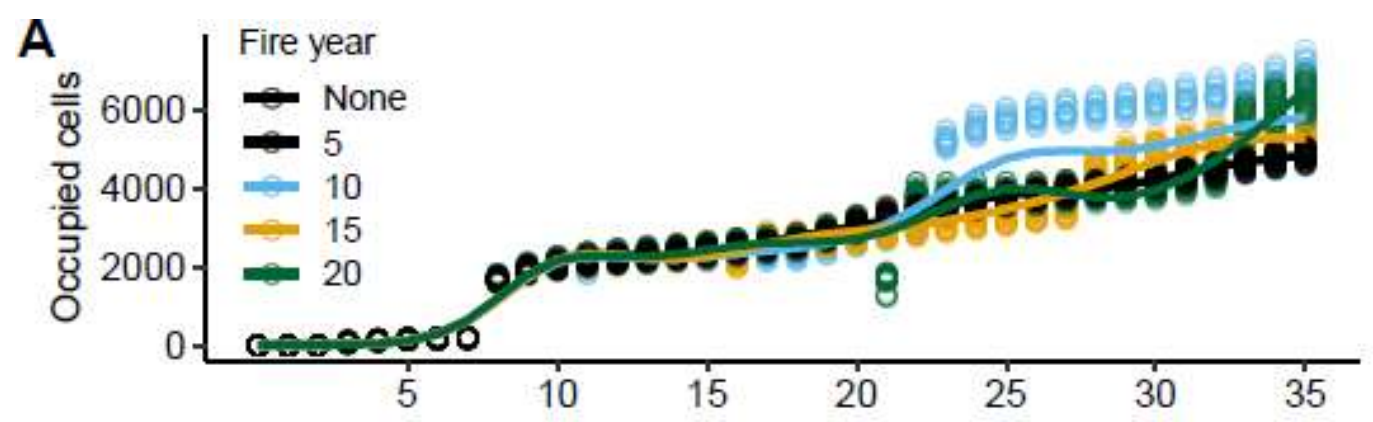

B

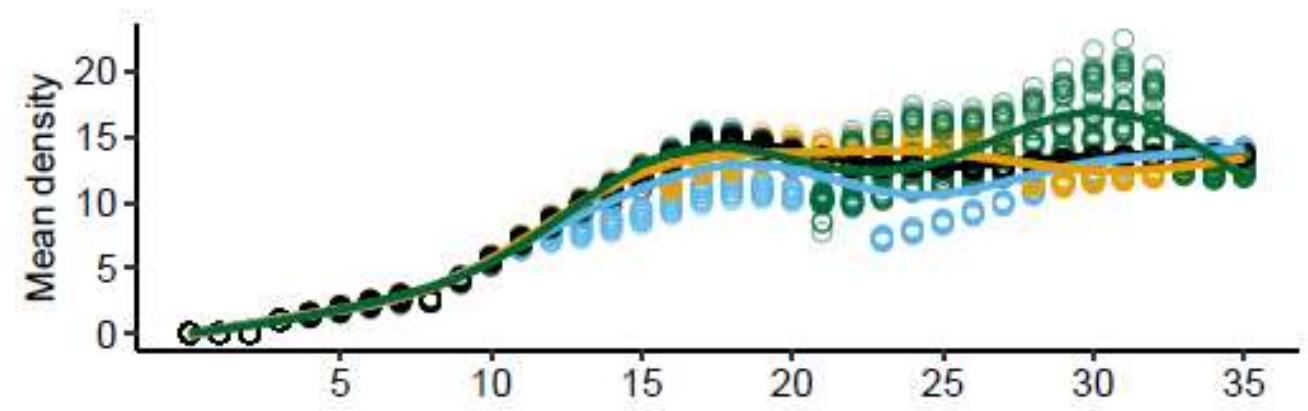

C
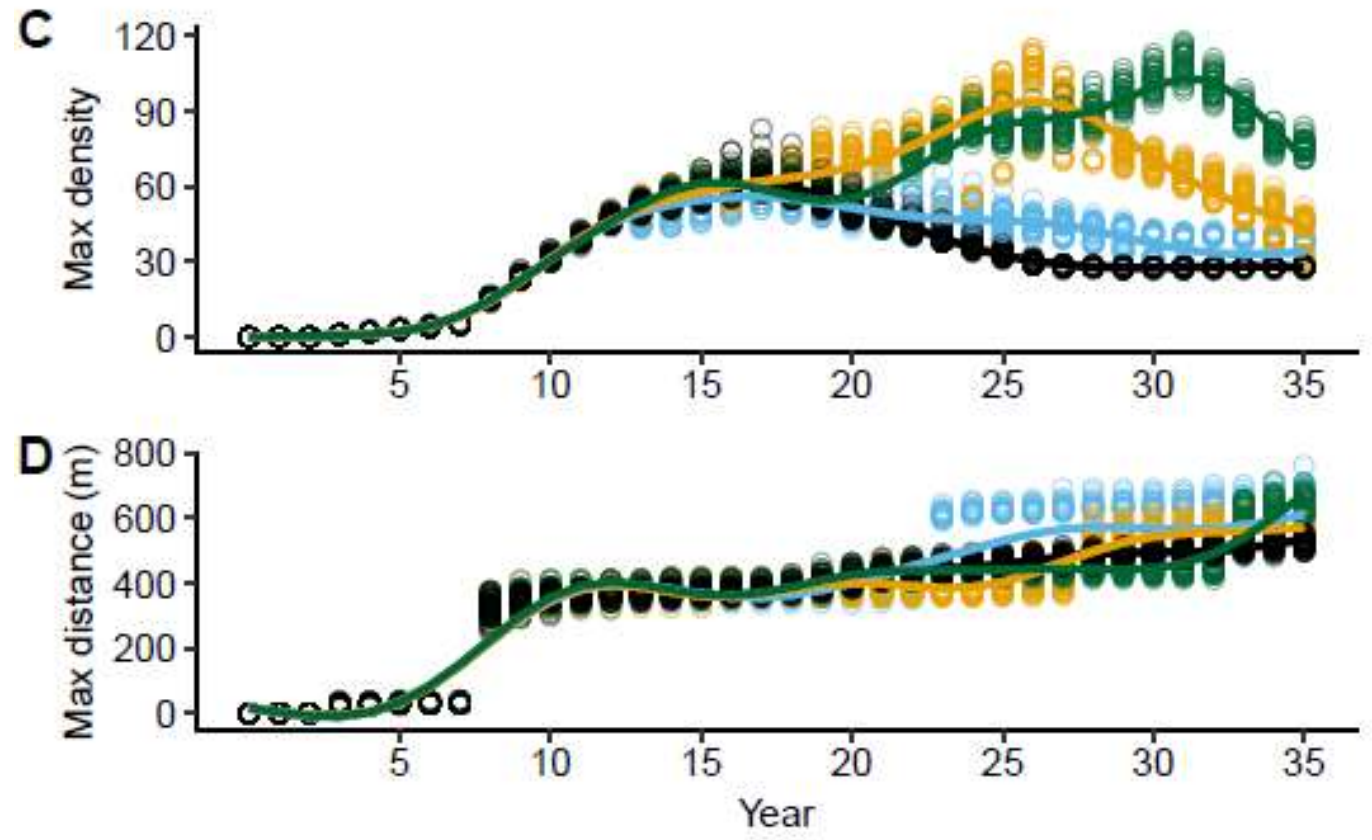

718 